Ministerstwo Nauki

i Szkolnictwa Wyższego

Digitalizacja archiwalnych numerów czasopisma naukowego Analecta Cracoviensia 1-24 (1969-1992)

i ich publikacja w otwartym dostępie - zadanie finansowane w ramach umowy 672/P-DUN/2017 ze środków

Ministra Nauki i Szkolnictwa Wyższego przeznaczonych na działalność upowszechniającą naukę

O. AUGUSTYN JANKOWSKI OSB

\title{
SYMBOLIKA TRZECIEGO JEZ̃DZ̃CA APOKALIPSY (Ap 6, 5n.)
}

WOBEC NOWEJ PROPOZYCJI

W numerze 43(1500) „Tygoodnika Porwszechnego” z 23 X 1977 r. Roman Brandsitaetter zamieścił artylkuł pit. Kim jest Trzeci Jeździec Apokalipsy? $\mathrm{Na}$ zadane w tym tytule pytanie odpowiedział Autor, podając zupełnie nowy przekkad i interpretację tego symbolu, tym samym oldstępując od tej, którą przyjmuje się idziś powszechnie zgodnie $\mathrm{z}$ wielowniekkorwą tradycją. Jego zdaniem Trzeci Jeździec trzyma w ręgu nie wagę, lecz jarzmo. W następstwie tego sam Jeździec nie jest symbolem klęski głodu, lecz ucisku społeczmego. Takie tłumaczenie R. Brandsitaetter powtórzył w przekłaadzie pism Janowych ${ }^{1}$. Ponieważ wyżej przyitoczony artykuł cytuje takkże i moje komentarze do Apookalipsy ${ }^{2}$, w których zreferowałem powszechnie przyjmowane stanowiskio, poczuwam się do obowiązkru zabrania głosu $\mathrm{w}$ sprawie tej nowej propozycji. Zważywwszy jednak argumenity autora nie mogę $\mathrm{z}$ nią się zgodzić. A dlaczego - posstairam się tutaj szerzej uzasadnić.

$$
\text { „WAGA” CZY „JARZMO?” }
$$

Powtórzmy to wsitępne i zasadnicze pytanie za R. B. Punktem wyjścicia nowej propozycji jest odmienny przekład greckiego tekstu Apokalipsy 6, 5:

Kai hote ènoixen tèn sfragída tēn trítēn, èkousa tou tritou zōou légontos:

erchou.

kai eidon:

1 Pisma św. Jana Ewangelisty. Ewangelia, Listy, Apokalipsa (Pismo św. Nowego Testamentu), Warszawa 1978.

2 Apokalipsa św. Jana. Wstęp - przekład z oryginału - komentarz, Poznań 1959; A. Janikowski, K. Romaniuk, L. Stachorwiak, Komentarz praktyczny do Nowego Testamentu, Poznań — Warsizawa 1975, 1139—1201. 
kai idoù hippos melas, kai ho kathēmenos ep'autòn echōn zygòn en tē cheirì autoû.

Ten wiersz $\mathrm{w}$ tłumaczeniu R. Brandstaettera brzmi:

A gdy zdjął trzecią pieczęć,

Usłyszałem trzecie Stworzenie

Wołające:

„Przyjdź!”

I ujrzałem

- Spójirz! -

Oto czarny ksoń,

a na nim jeździec,

Który trzymał w swej ręce jarrzmo.

W tłumaczeniu tym killka szczegółów jest kontrawersyjnych. Można pominąć tu nieistotne dla naszej sprawy: podział na stychy, dylktowany przez licentia poetica, przekład słów ēnoixen oraz idoù. Istotne jest oddanie zygón za pomocą ja r z ma. Odbiega to od powszechnie przyjmowanej tutaj wa gi, która figuruje nie tylko w przekładach i komentarzach, ale również $\mathrm{w}$ fachowych słownikach jako właściwe mnaczenie tego wyrazu w Ap 6, 5.

Grecki termin zygón (attycki) lub zygós ${ }^{3}$, podolonie jak łacińskie iugum, oparte na tym samym źródłosłowie indoeuropejskim* iug-, zawierają $\mathrm{w}$ sobie pierwotne pojęcie belki poprzecznej. Taką jest jarzmo, taką również - zasadnicza część pierwotnej wagi, z zawieszonymi na niej szalami. Wyrazy te nadto tak u Greków, jak u Rzymian oznaczały również poprzeczną ławkę i reję na masizcie. W słownikkach greki klasyczmej pod hasłem źygós, zygón pierwszeństwo ma ,jarzmo” przed „wagą”. Odwrotna sytuacja jest $\mathrm{w}$ słowniku G. Kittela; przy omawianiu tego terminu w Starym i Nowym Testamencie, za każdym razem, pierwszeństwo uzyskuje "waga" ", zapewne pod sugestią hasła tego w klasycznej Konkordancji do Septuaginty ${ }^{5}$, gdzie cyfrą 1 opatrzony zostal zygós jakıo przekład hebrajskiego mo'znajîm i aramejskigo mo'znajîn, występujący 17 razy w lksięgach kanonicznych ST. Te dane leksylkalne ukkazują jednocześnie możliwość teoretyczną obydwu przekłładów omawianego terminu z Apokalipsy i praktyczną opcję autorów za powszechnie przyjmowaną „wagą".

Uznając tę wykładnię za ,jednomyślną i powszechną", R. Brandstaetter świadomie ją odrzuca. Pomijając tu samą genezę tej — jak sam

3 W Ap 6, 5 rodzaj meski czy nijaki tego rzeczownika jest nie do ustalenia, gdyż jest to accusativus. Na podstawie analogii do tłumaczenia LXX powszechnie przyjmuje się męską formę zygós.

4 Por. B. Bertram - K. H. Rengstorf, zygós, ThWNT II, 898-903.

5 Por. E. Hatch - H. A. Redpath, A Concordance to The Septuagint, vol. I, Graz 1954, 599. 
nazywa - "przygody egzegetyczne", mianowicie oglądanie ilustracji do Apokalipsy wykonanych przez Albrechta 6 Dürera, wśród których „waga powiewająca $\mathrm{w}$ ręce trzeciego Jeźdźca [...] o filigranowych kształtach kołysząca się filuternie w powietrzu", nie wydała się adekwatnym symbolem nadchodzącej klęski głodu, przejdźmy do fachowej argumentacji, zawartej w artykule. Streścić ją. można następująco:

1. Waga w ST czy jako hebrajskie mo'znajîm czy jakko grecki zygós nigdy nie jest symbolem skąpego odmierzania racji żywwnościowych w czasach głodu.

2. Przyczyną błędu egzegetów jest niewłaściwe odczytanie dwóch teksstów ST - Kpł 26, 26 oraz Ez 4, 16 - kstóre mówią o „ciężarze” (miškal), a nie o wadze-przyrządzie, co już zauważyli tłumacze LXX oddając hebrajski termin greckim stathmós.

3. Wypowiedź z Ap 6, 6 o ciężkiej doli ludu praoującego, malująca ucisk społeczny przylega do symbolicznej wartości jarzma trrzymanego w ręce przez Trzeciego Jeźdźca.

4. Zakkaz „nie krzywdź oliwy i wina!” $(6,6)$ odnosi się do warunków palestyńskich i stanowi - zgodnie $\mathrm{z}$ symboliką jarzma - napomnienie pod adresem krzywdzicieli i wyzyskiwaczy, którzy biedocie pracującej płacą nędzne wynagrodzenie za całodzienny trud, odbierając im możność uczestniczenia w s a c r u m, gdyż zboże, oliwa i wino są symbolami opieki Bożej nad wyznawcami Boga Jedynego ?

'Nerwem argumentacji R. Brandstaettera jest zattem odrzucenie znaczenia „wagi” jalko błędnego interpretamentu egzegetów, a uzasadnienie znaczenia „jarzma" mentalnością hebrajską i stosunkami palestyńskimi, które się dają odczytać z kontekstu. Metodą zaś jest analiza samych terminów zachodzących w tekście, poparta danymi tła wyłącznie palestyńskiego.

W niniejszej próbie obrony powszechnie przyjmowanego stanowviskka waga symbolem klęski głodu - kwestionuję zarówno nerw argumentacji, jak i obraną przez Brandstaettera metodę jako jednostronne. Uznając w pełni to, że św. Jan, autor Apolkalipsy, myśli po helbrajskku pisząc po grecku, trzeba pamiętać, iż korzysta on ze Starego Testamentu w sposób solbie właściwy, można powiedzieć surwerenny, a horyzont jego wizji wykraicza daleko poza Palestynę - jest uniwersallistyczny, a więc z koonieczności też rzymski.

"W antykule zachodzi błąd w imieniu „Alberta". Nawiasem może wanto wspromnieć, że ilustracje Dürera do Apokalipsy "na nazwę ,genialnyich" nie zasłużą sobie u egzegetów. Wibrew bowiem gatunkowi literackiemu tej ksiegi usiłują w sposób bardzo realistyczny odmalować czy nakreślić to, co się nie da w ten sposób wyrazić. Jakże niefortunne jest rysowanie Barankowi siedmiu rogów!

7 Powyższe streszczenie trzyma. się możliwie dosłownych wyrażeń cytowanego antyikułu R. B. - mimo nie sitosowania cudzysłowów. 


\section{CIĘŻAR - WAGA - GEOD}

Dwa pierwsze punkty argumentacji Brandstaettera przeciw stanowisku powszechnie dziś przyjmowanemu opienają się na milcząco przyjjętych założeniach, które nie są przekonujące. Mianowicie: ponierważ hebrajiski termin mo'znajîm, będący, proponowanym odpowwiednikiem terminu zygós jalko wagi, nigdzie nie jest w ST symbolem skąpo wyldzielanych racji żywnościowych, zatem mie może być nim i, lw Apokialipsiie. Innymi słowy: Janowa symbolika nie może wylkraczać poza skiarlbiec Starego Testamentu. Otóż tak nie jest. Sw. Jan jak może żaden inny autor NT korzysta z materiałów ze ST, ale korzysta w spoisób suwerenny, đzin. oryginalnie zestalwiając te elementy przyjęte, modyfikując je, a także włączając zupełnie inne. I tak nie są wzięte jako c ało'ści ze Sitarego Testamentu: ani Baranek, ani Zwierzęta, które Brandistaetter woli tłumaczyć przez „Stworzenia” ( $z \overline{0} a)$, ani Niewiasta obleczona w słonce, choć poszczególne ich składmiki odnajią się w Starym Testamencie.

Dalisze millczące założenie jest to, że za greckim zygós ma sitać termin mo'znajîm, tak bardzo - zdaniem Brandstaettera - nieadekwatny, jeśli miałby być symbolem klęski głodu. Tymczasem to nie jest ścisły odpowiednik, jeśli weźmiemy pod uwagę język Septuaginty. To bowiem tłumaczenie sporządzone przez Żydów, za pomocą terminu zygós oddaje mie tylko mo'znajîm, ale również $m^{e}$ śûrā $[h]$ w Kpł 19, 35 w znaczeniu mierzenia objętości: „Nie będziecie popełniać niesprawiedliwości w wylrokkach, w miarach, w wagach, w objęt o ści". Przy czym liczba mnoga (en zygois) zestawiona $\mathrm{z}$ liczbą pojedynczą $\mathrm{w}$ tym miejscu hebrajskiego rzeczownilka $m^{e}$ śûra $[h]^{8}$ sugerulje różne miary objętośai płynów czy ciał sypkich, a więc różnego rozmiaru naczynia stossowane przy odmienzamiu towarów płynnych lub sypkkich, analogicznie do wagi, użyıwanej — do pozostałych, wraz z odważnikaama, które w powyższym zdaniu stoją ma milejscu przedostatnim. Słorwo to w Septuagincie en stathmiois oddaje helbrajskie bammišqāl - dosłownie: ,w odważniku”. Drugi ten termin hebrajski, wspomniany $\mathrm{w}$ artykule $\mathrm{R}$. Brandsitaettera zostanie niżej omówiony w związku z zakwesitionowanym przez Brandstaettera jego tłumaczeniem u Ezechiela. Na razie wystarczy tyle: mórwiący po grecklu Żydzi posługiwali się terminem zygós w sposób dość elastyiczny: mogła to być dila nich nie tylko ,waga”, ale i „miara”. W oidważaniu bowwiem i w odmienzaniu był wspólny miamownik. Czyli nie w przyrządzie, lecz w c zynności samej thkwiła analogia w odczuciu tłumaczy starożytnych.

Teraz można już, przejść do merytorycznej oceny głórwnej tezy $R$. Brandstaettera, która brzmi: „Waga po helbrajsku moznajim, a po greaku

8 Ten sam bowiem rzeczownik w pozostałych dwóch krytycznie perwnych tekstach (Ez 4, 11.6) został w Septuagincie oddany przez greckie metron (en metrō[i]). 
zygos, nigdzie nie jeist w Starym i Niowym Teistamencie symbolem skąpego odmierzania racji żyıwnościowwych". Po tej tezie negatylwnej Brandstaetter stwierdza - całkiem słusznie - że w sensie dosłownym ,waga" w Starym Testamencie jest ,przyrządem do ważenila torwaru i pieniędzy”, natomiasist w sensie symbolicznym oznacza Sąd Boży i Sprawiedliwość Bożą. Ale czy tertium non datur?

Tej tezie negatywnej - na podstawie tego, co wyżej powiedziano o symbolach Apokalipsy i o zalkresie pojęć zygós w Septuagincie - należy przeciwsitarwić następującą tezę pozyttywną: greckie zygós Sepituaiginty zawierające $\mathrm{w}$ sobrie i przyrząd i jakkoś $\mathrm{c}$ z y n n o ść $w$ a żenia w tekstach Starego Testamentu pozostaje w związknu z kllęską głodu. Jak się okkaże $\mathrm{z}$ teksstów o symbolicznych czynnościach nakazánych Ezechielowi, przyjmowany przez Brandstaettera ,ciężar" zamiast ,wwagi”, którą odrzuca, jest od niej nieodłączny: nie ma określenia dokładnego ciężaru pokxarmu bez użycia wagi jalko przyrządu.

Symboliczna czynmość tego prorsoka - spoczywanie na boku nieruchomo i skąpe odżywianie się - ma stanowić obrazołwą zaporwieidź klęski, jalka czeka Jerozolimę: następstiwem jej oblężenia będzie głód. Prorok ma solbie przygotować chleb z sześciu ziemiopłodów, a jednorazowa porcja dzienna tego pożywwienia będzie nad wyraz skąpa: „Waga tego polkarmu, który będziesz spożywał, wyniesie 20 syklów" (Ez 4, 10). Jest to nieco ponad 228 gramów $^{9}$. Znikomość tej racji żyẉnościowej harmonizuje z równoczesnym nakazem oszczędnego picia wody, której dzienna racja dla prorokka ma wynosić $1 / 6$ hinu, a więc mieco ponad litr według jedmego syste$\mathrm{mu}$ przeliczania, a zaledwie połorwę tego - wedhug drugiego ${ }^{10}$. Na warunki życia w Palestynie jest to bardzo mało. W tekście następuje niedwuznaczne wyjaśnienie, czego to ma być zapowiedzią: „Synu człowieczy, oto złamię podporę chleba w Jerozolimie tak, że będą jeđlli chleb ściśle odważony i ze strachem będą pili wodę ściśle odmierzoną, aby cierpiąc niedostatek chleba i wody, jeden po drugim omdlewali i niszczeli w swych grzechach" (Ez 4, 16).

Omawiając ten tekst wraz z analogicznym z Kpł 26, 26, R. Brandstaetter słusznie akcentuje, że polskie słowo „waga” i „odważony” są w nim. tłumaczeniem nie ,wagi” (mo’znajîm), lecz „ciężaru” (bemišqāl). Tej różnicy zresżtą w pełni są świadomi ruczeni podtrrzymujący tradycyjną i powszechną wylkładnię ${ }^{11}$, a mimo to od niej nie odsitępują. Różnica ta bo-

${ }^{9} \mathrm{Sykl}=11,424 \mathrm{~g}$ podaje J. Trinquet, Métrologie biblique, w: DBS V, 1247. Za nim to samo przeliczenie podaje H. Haag, Bibel-Lexicon, Leipzig 1969, 1954.

10 Por. H. Haag, tamże, 1951.

11 ,Die Waage als Symbol der Teuerung hat vielleicht in Lv 26, 26; Ez 4, 16 ihr Vorbild, wo allerdings das Wort zygós nicht vorkommt. Im Grundtext steht mišqäl; LXX: stathmos" (K. H. Rengstorf, zygós im NT, w: ThWNT II, 901). Znamienne jest $w$ cytowanych wyżej słowach lekkie wahanie co do tego, czy oba wspomniane teksty ST były wzonem. Z dalszego ciągu naszych wywodów wyniknie 
wiem bynajmniej nie stoi wpoprzek drogi semantycznej „ciężar” — „waga" - „głód”, która jest u podstawy symboliki Trzeciego Jeźdźca Apokalipsy. Akcentując tę różnicę $\mathrm{w}$ swym artykule Brandsitaetter powołuje się na Septuagintę: „Swiadomi tych różnic byli tłumacze Septuaginty, którzy prawidłowo przełożyli miszkal ${ }^{12}$ za pomocą greckiego stathmos, a nie $z y g o s, '$ a Martin Buber w swoim niemieckim przekładzie Starego Testamentu na określenie miszkal słusznie użył słowa Gewicht, a nie die Waage". Rzeczywiście - takie jest znaczenie tego terminu jako rzeczownika. Wszakże w różnych złożeniach nabiera on nieco innego znaczenia,

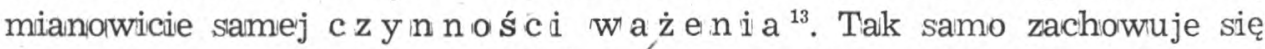
przytoczony grecki jego przekłład w Śeptuagincie - stathmós, z tym, że $\mathrm{w}$ jednym miejscu idzie on jeszcze dalej, przechodząc od czynności do narzędzia: „szala" i ,waga", stojące w roli pojęć symonimicznie paralelnych - to właśnie te, które R. B. kategorycznie oddziela: stathmós i zygós: tak jak w Iz 40, 12 de:

„Kto zważył góry na wadze (hebr.: peles; LXX: stathmós),

i pagórki na szalach (hebr.: mo'znājîm; LXX: zygós)".

Oba wyżej cytowane terminy hebrajskie jalko paralelne łącznie występują w tekście: „Waga (peles) i szala (mo'zne [i] ${ }^{14}$ — to sprawa Jahwe" (Prz 16, 11).

Jak zatem widać z powyższego zestawu tekstów tak hebrajskiego, jak greckiego Septuaginty, nie ma podstaw takkie rozgraniczenie pojęć ,wagi". i „ciężaru”, które uchylałoby jako „nieporozumienie” uzasadnienie wagi symbolizującej klęskę głodu dwoma cytowanymi tekstami z Księgi Kapłańskiej i Ezechiela. Przeciwnie sama już terminologia nasuwa przesuwanie. się znaczenia kwestionowanych przez Brandstaettera słów od „ciężaru” poprzez „ważenie” do przyrządu, a więc „wagi”. Związek z głodem nie wymaga tuzasadnienia - jest na przykładzie symbolicznej czynności pro-

że ta ostrożność ma uzasadnienie: nie tylko bowiem te dwa miejsca mogły naprowadzić św. Jana do posłużenia się tym symbolem, jeśli w ogóle jako wizjoner miał tu jakąkolwiek wolność wyboru.

12 Uproszczoną transliterację fonetyczną słów hebrajskich podaje stale w swoim artykule R. Brandstaetter.

13 Oddaje ją łacińskim słowem ponderatio F. Zorell, Lexion Hebraicum et Aramaicum Veteris Testamenti, Roma 1950, 486, stawiając to wlaśnie 'czynnościowe znaczenie przed pondus. Jako przykłady tego znaczenia podaje: Kpl 19, 35 (wyżej tu przytoczone); Ez 5, 1 (o którym niżej będzie mowa) oraz metaforyczne: Syr 6, 15, gdzie w LXX mamy znów stathmós, też wykraczający poza znaczenie "ciężaru". Dalej połączony $\mathrm{z}$ przyimkiem be w formie: bammišqal ( $\mathrm{Kpl} 26,26)$ lub bemišqal (Ez 4, 16) implikuje czynność ważenia, odmierzania ciężaru na wadze. Por. precyzyjne tłumaczenia zwrotów tych, jako genau abgewogen, a zwrotów: $l \bar{o} ’ h \bar{a} j \bar{a}$ mišqāl $=$ „war nicht zu wagen” oraz 'ê(i)mišqāl = „unwägbar viel” podane w: B. Baumgartner, Hebräisches und Aramäisches Lexicon zum Alten Testament, II, Leiden 1974, 617. Wszędzie tam występuje już c z yı n no ść ważenia.

14 Status constructus od mo'znājîm z racji następującego potem w tekście masoreckim wyrazu mišpāt, który wydawcy usuwają. 
roka wręcz oczylwisty. Prorok głodowe swoje porcje musiał odważać na wadze. Właśnie waga, i to mo’znājîm, musiała się znaleźć w ręku proroka na rozkaz Jahwe przy innym równie symbolicznym jego działaniu, które następuje bezpośrednio po znaku skąpego odżywiania się, w ramach zapowwiedzi oblężenia Jerozolimy: „Synu człowieczy, weź sobie ostry miecz i użyj go jakko brzytwy i ogol nim isobie głowę i brodę: następnie weź dokładiną wagę (mo'znē $[i]$ mišqāl - zestaw terminów, które Brandistaetter kategorycznie od siebie oddziela) i podziel (ogolone włosy)" (Ez 5, 1). Od „wagi", która tu jest nie symboliczna, lecz konkretna, ale użyta do czynności symbolicznej, prosta droga wiedzie do "wagi" - symloolu rzeczywistości ukazanej w znaku. Droga zatem: „ciężar” — „waga” — „głód” nie jest błędna.

W krytyce, jaką przeprowadza Brandstaetter, wykładni tradycyjnej pada słowo „,egzegeci”. Czy rzeczywiście od nich zaczęło się ow o, jak określa, „nieporozumienie"? Przed egzegetami byli już w starıżytności anonimowi autorzy przekładów powszechnie używanych. Grecki termin zygós w Ap 6, 5 przekładają oni jako ,wagę", nie jalko ,,jarzmo". I tak Vetus Latina i Wulgata maja wyraz statera, a oba przelkłady syryjsskie (filokseniańskie i harkleńskie): ma'satā. Trudno przypuszczać u nich zależność od wspomnianych przez Brandsitaettera tekstów Starego Testamentu, niewłaściwie interpretowanych. „Waga” była dla nich po prostu znaczeniem bardziej właściwym. Czy na ten wylbór wpłynęły względy doktrynalne czy filologiczne ${ }^{15}$, trudno dziś rozstrzygnąć. W każdym razie to zgodne świadectwo kościołów tak od siebie odległych - od Afryki prokonsularnej po Mezopotamię - ma swój ciężar gatunkowy w naszej kontrowersji.

\section{DODATKOWE POTWIERDZENIA DLA SYMBOLIKI TRADYCYJNEJ}

Niezależnie od wyżej przedstawionej argumentacji - nowwego confirmatur dostarcza Stary Testament dla tradycyjnej symboliki Trzeciego Jeźdźca, ocenianej łącznie z symboliką Drugiego i Czwartego. Z czterech Jeźdźców do dziś dnia kontrowersyjny jest tylko pierwszy. Czy jest on symbolem zwycięslkiego militaryzmu ówczesnych mocarstw, czy też zwycięskiego pochodu Ewangelii - nie pora tutaj rozstrzygać. Znamienna jest natomiast zgoda powszechna komentatorów na trójcę pozoistałą: Drugi - to wojna, Trzeci — to głód, Czwarty - to śmierć jakko zagłada masowa. Czy przyczyną tej zgodności jest tylko oczywwista wymowa symbolów? Nie tylko. Drugą racją - i ta właśnie jest pomocna w obecnej

15 Filologiczne o tyle wyglądają bardziej prawdopodobnie, że na ogół łacińskim przekłaidom starożytnym zarzuca się zbytnią dosłowność. Nadito zygós (= waga) i choiniks (= nasza „kwarta”, hebr. bat) występują razem u Ez 45, 10 (LXX) tak, jak w Ap 6, 5n. 
konitrowersji - jest argument zaczerpnięty z pism prorockich Starego Testamentu. Stanowią go typorwe zestawy klęsk, które są karami za grzechy.

"Apolksalipsa Janolwa jako również „proroctwio” (Ap 1,3) ma wiele cech tego biblijnego gatunku literackiego, a wśród nich - posługilwanie się tzw. „kliszami”, tj. tymi samymi obrazami przy omawianiu powttarzających się tematóiw. Sw. Jan wprawndzie w spoosób oryginalny, soibie waściciwy, korrzysta ze wzorów swoich poprzedinikóiw - proroków Starego Testamentu, niemmiej chętnie posługuje się ich gotowymi , "klisizami”, zwłaszcza przy zbieżności tematów. Stąd prorocy grożący niewiernemu ludowi klęskkami jakko karą Bożą stanowili i dla apokaliptyki właściwe natchnienie przy obrazowaniu klęsk eschatologicznych, jalkie mają spaść na całą ludzkoość. To samo widzimy także w Janowej Apoikalipsie, w której te klęski stanowią zwiastuny Wielkiego Dnia Gniewu ${ }^{16}$.

Otóż u wielkich prorolków ta sama trójca klęsk: miecz, głód i śmiercionośna zarraza powtarza się ibardzo /wiele razy ${ }^{17}$. Co jest znamienne, że choć nie za'wsze występuje tam „miecz” a ,zaraza”, ito jednalk nigdy nie brakkuje ,głodu". Prizy czym analogie z Ezechielem są tu najbbardziej wymowne. Z tego bowwiem proroka szczególnie dużo elementów obrazoiwych zaczerpnął św. Jan, żeby tylko wspomnieć na nim wzorowane Cztery Zwierzęta - cheruby świata materii, kssięgę na dłoni Boga jako Zasiadającego na tronie, znakku na czołach ludzi wyibranych, księgę do spożycia przez prorokia-wizjonera, mierzenie trzciną miasta Bożego i życiodajną rzekę wypływającą ze świątyni. Podobnie, jak wyżej już wsspomniano, u Ezechiela właśnie waiga służy do czynności symbolicznej związanej z zapowiedzią klęski.

Właśnie Drugi, Trzeci i Czwarty Jeździec Apokalipsy stanowią odbitkę takiej ,"kliszy” prorockiej. „Miecz" wysistępuje w oibrazie Pierwszego z nich $(\mathrm{Ap} 6,4)$, a przy Czwartym, wyraźnie nazwanym „Śmiercią” wspomina się całą Ezechielową $(14,21)$ czwórkę: „miecz, głód, mór i zwienzęta ziemi". Wspommiany zatem, ,głód" oldpowiada dolkładnie Trzeciemu Jeźdźcowi. W ten sposób Apookalipsa kontynuując linię prorroków Starego Testamentu podaje tu klasyczne przylkłady klęsk zsyłanych przez Boga jako kaary. Wśród tych klęsk nigdy nie brak głodu. Dziiwne by było jego

16 Por. zapowiedź kary na Wielki Babilon: „...w jednym dniu nadejdą jej plagi: śmierć i smutek, i głód; i będzie ogniem spalona, bo mocny jest Pan Bóg, który ją osądził" (Ap 18, 8).

17 Unaoczni to następujący zestaw:

Izajasz: 51,19 (cała trójca + spustoszenie)

Jeremiasiz: 5, 12 (miecz i głód); 11, 22 (tak samo); 14, 12 (cała trójica); 15, 2; 16, $4 ; 18,21,7.9 ; 24,10 ; 27,8 ; 32,24.36 ; 34,17 ; 38,2 ; 42,17.22 ; 44,13$ (wsizędizie cała trójca)

Ezechiel: $5,12.17 ; 6,11 n . ; 7,15 ; 12,16 ; 14,21$ (zawsze cała trójca, a w ostatnim wypadku jest czwarta plaga: dzikie zwierzęta). 
pominięcie w Appokalipsie, gdylby Trzeci Jeźdżiec nie miał oznaczać głodu, umieszczony między ,wojną" a ,śmiercią”, określonymi jedmoznacznie.

Znacznie jednak bliższa i jeszcze bandziej przekonująca jest paralela, jaka zachodzi między Janową Apokalipsą a tzw. apokalipsą synoptyczną czyli zapowiedziami zwiastunów końca świata, jakie czytamy w Ewangeliach symoptycznych.

\section{$\mathrm{Mk} 13,8$}

Powstanie bowiem naród przeciw narodowi i królestwo przeciw królestwu; będą miejscami trzęsienia ziemi, będą klęski g ło du. To jest początek boleści. 玉k 21, 10n.

Powstanie naród przeciw narodowi i królestwa przeciw królestwru. Będą silne trzęsienia ziemi, a miejscami głód i zaraza; ukażą się wielkie i straszne znaki na niebie.
Mt 24, 7n.

Powstanie bowiem naród przeciw narodowi i królestwo przeciw królestwu. Będzie głód i zaraza, a miejscami trzessienia ziemi. Lecz to wszystko jest dopiero początkiem boleści.

Jak widać, wśród klęsk poprzedzających paruzję nigdy nie braak głodu. Warto od razu zaznaczyć, że wzmianka o narodach i królestwach, stale zachodząca, wsikazuje na hóryzont powszechny, a nie lokalny, palestyński tych wizji. Tak samo jest w Apokalipsie Janowej. W niej nadto wymaźnie klęska głodu - już bez symbollu, jalk w omawianym miejscu - jeszcze dwukrotnie występuje $\mathrm{w}$ ramach trójcy klęsk znanych $\mathrm{z}$ proroków: przy skutkach działania Czwartego Jeźdźca (Ap 6, 8) i w ramach zapowiedzi upadku „Wielkiego Babilonu” — Rzymu: ,w jedny"m dniu nadejdą jej plagi: śmierć i smutek, i głód; i będzie ogniem spalona..." (Ap $18,8)$.

Nie dziwimy się więc tradycji egzegetycznej, która od początku ${ }^{18}$ trzyımała się stale tej jedinej interpretacji: Trzeci Jeździec - to klęska głodu.

\section{OCENA POZOSTAEYCH ARGUMENTOW ZA „JARZMEM”}

Nowa ${ }^{19}$ interpretacja, jaką wysunął $R$. Brandstaetter, ma również pozytywne w cytowanym artykule uzasadnienie. Opiera się ono mianowi-

${ }_{18} \mathrm{U}$ jednego z najstarszych komentatorów Apokalipsy, u św. Wiktoryna z Poetovio (Pettau), czytamy - według recenzji św. Heronima - następującą interpretację: „Equ u s autem niger famem significat; ait enim dominus: e t er it f a m es per loca. proprie autem extenditur uerbum usque ad Antichristum, id est tempora, quando magna fames est futura quandoque et homines (lub: omnes) laedentur. Statera in manu: libra examinis, in qua singulorum merita ostenderet" (Victorini Episcopi Poetovionensis opera, rec. I. Haussleiter, CSEL 49, Vindobonae-Lipsiae $1916,70 \mathrm{n}$.). Znamienny jest kontrast: waga oznacza wprawdzie Bożą sprawiedliwość, ale Jeździec - właśnie przez analogię do zapowiedzi Pańskich synoptycznych - głód jako zwiastuna paruzji. Za nim poszedł ostatnio A. Läpple, o czym niżej.

19 Nową można nazwać tę interpretację w znaczeniu względnym, tzn. gdy chodzi o uzasadnienie. Sam bowiem pomysł oddania wyrazu zygós przez ,jarzmo" miał 
cie na szczególnym znaczeniu, jakie nadaje ten autor następnemu wierszorwi:

„I usłyszałem jakby głos z pośrodlka czterech Zwierząt, mówiący: «Kwarta pszzenicy za denara i trzy kwarty jęczmienia za denara, a nie krzywdź oliwy i wina!»" (Ap 6, 6).

Pierwsze dwa stychy tego wiersza interpretuje Brandstaretter rozwijając konselkwentnie swoją symbolikę jarzma jako ucisku społecznego. „Głos spośród Czterech Stworzzen... wyporwiada pogląd na ciężkie materialne położenie najemnego robotnika rolnego, który za jeden dzień żmudnej, dwunasistogodzinnej pracy otrzymuje wynagrodzenie jednego denara czyli elkwiwalent jednej miary pszenicy lub trzech miar jęczmienia". Przy tym jeist zdania, że jest to ,wypowiedź... malująca ucisk społeczny, który wbrew nakazom Tory panował w Palestynie". Na czym opiera się przypuszczenie, że $\mathrm{w}$ ogóle mowa tu jest o najemnym robotniku nolnym? Tylko na jednym szczególe - na wspomnianym ,denarze”, znanym nam z przypolwieści o robotnilkach w winnicy: „Umówił się z roboitnikami o denara za dzień..." (Mt 20, 2.9.13). Fundament to o tyle niepewny, że stawka denara bynajmmiej nie była stała. D.niówlki bowiem palestyńskie - jak świadczy Talmud - wahały się ad pół denara do dwóch ${ }^{20}$. A zatem znacznie prościej ljest $\mathrm{w}$ naszym tekście oceniać owego denara nie jalko dniówkę najemnego robotniki, lecz po prositu jako obiegową jednostkę monetarną. Choidzi po prositu o poidanie ceny artykułów spożywczych. Nadto wąski horyzont palestyński nie harmonizuje z powszechnym, ogólnoświatowym, zasięgiem klęsk opisanych przy ukazaniu się Drugiego i Czwartego Jeźdźca. Stąd też stosunki panujące w ówczesnym imperium zdają się trafniejszym punlktem odniesienia dla danych tu wzmiankowanych. I tak ,kwwanta" (chojniks = ok. 1,08 1), miara grecka, a nie starotestamentowa, uchoodziła u Greków za dzienną rację pszenicy dla żołnierza ${ }^{21}$. Jeśli się przy tym uzna za orientacyjną dniówkę jednego denara, to za tę cenę nie mógł nikt utrzymać całej rodziny. Senat rzymski za denara ustalał ośmiokrnotnie większą rację pszenicy ${ }^{22}$. Obraz

już dawno swych przedstawicieli: ,Woodhouse and others insist on the meaning "yoke" - undenstanding "the yoke of ceremonies" poidaje The Holy Bible, ed. F. C. Cook, London 1881, New Testament IV, 574. Interpretacja słusznie zarzucona jako zupełnie obca względem kontekstu i całego obrazu.

20 P. Billerbeck, Kommentar zum Neuen Testament aus Talmud und Midrasch. Bd. 1, München 1958, 831. „Mamy cały szeneg świadectw o tym, ile zarabiali robotnicy w Rzymie, Egipcie i Palestynie. Wlidać z nich jednak, że wysokość zarobku robotnika nie była ścisle określona" (F. Gryglewicz, Najemny robotnik $w$ Palestynie za czasów Chrystusa Pana, w: ,Zeszyty Towarzystwa Naukowego KUL” 5, (1958), 90).

21 Tak podają: Herodot (VII 187), Atenajos (III 20), Diogenes Laertios (Pythagoras VIII 18) i Suidas (s. v. Pythagoras). Natomiast tTukidydes (IV 16) dla Spartan podaje rację dwoukrotnie większą.

${ }^{22}$ „Nam quum ex senatusconsulto et ex legibus frumentum ei in cellam sumere 
klęski głodu jest więc wyraźny, choć uzyskany drogą pośrednią — przez poddanie 'wygórowanych cen za zboże ${ }^{23}$. Ten sam sposób określania klęski głodu stosuje już Stary Testament: „Powstał zatem wielki głód w Samarii. Bo oto nieprzyjaciele oblegali ją tak, iż głowa osła kosztowała 80 srebrnych sylklów, a ćwiartkika kaba dzilkiej cebuli pięć sylklów srebra" (2 Krl 6, 25). Odwrócenie zaś klęski jest zapowiediziane norwą zmianą cenniksa artylkułów piemwszej potrzeby: „Jutro o tej samej porze jedna sea najczystszej mąki będzie za jednego sykla, dwie sea jęczmienia też za jednego sykla — w bramie Samariii" $(2 \operatorname{Krl} 7,1)$.

Końcowa część wypowwiedzi tajemniczego , jakkby głosu”, bardzo zagadkowa i kontrowersyjna: „A nie krzywdź oliwy i wina!” (Ap 6, 6) otrzymuje u Brandstaettera nowe wyttłumaczenie. Można je streścić do nasitępujących twiendzeń: 1. „Oliwa î wino spełniają w codziennym życiu Izraela potrójną funkcję: odżywczą, leczniczą oraz salkralną (symmbole mesjańskie)”; 2. u Hebrajczyków ,oliwka i winograd na podobieństwo człowieka podlegają stanom uczuciowym”; 3. „krzywdziciel krzywdzi nie tylko bbiedaka, ale krzy:widzi tórwnież winnicę i oliwiki, które są przeznaczone do oddawania chwały Panu w salkralnych obrzędach": stąd ositrze-żenie; 4. „wartość symbolu sakralnego, na równi z winem i oliwą, poisiada również zboże" - $\mathrm{z}$ powołaniem się na Proroka Joela $(2,18$ n.). Wnioseik: protesit przeciw jarzmu ùcisku społecznego.

Twiendzeniom tym, branym z osobna, inie można odmóiwić słusżności. Tym niemniej mie ulkładają się one w spójną całość, która by wyjaśniła słowa „nilby głosu” w tym właśnie kontekście. Ani bowiem sam horyzont palesstyński nie ma tu zasitosiorwania, ani ,głosu" nie da się zredukiować do ostrzeżenia przed krzylwdą, ziwłaszcza krzywdą wciąż owego hipotetycznego pracownika najemnego, na kstórego w tekśsie nic nie wskazuje. Stąd i wniosek końcowy nie jest przekonujący.

Poprawny komentarz tego wiersza musi się liczyć $z$ dalszym i bliższym kontekstem, dalej musi sprecyzować, czyj głos i do kogo się odzywwa, wreszcie, jalk połączyć dwwie jego części: obiektywwną zapowiedź z następującym po niej zakizazem.

Nasz telkst należy do pierwszej siódemki - pieczęci. Chrysitus-Baranek jako Pan ludzkich dziejów je otwwiera, tzn. dzieje ludzkkie do końca

liceret, idque frumentum senatus ita aestimasset, quaternis sestertiis tritici modium, binis hordei... quum in Sicilia sestertiis binis modius esset... summum sestertiis ternis..." (M. T. Ciceno, In Verrem III 81). Sesterc - to jedna czwarta denara, a rzymski modius zawieral 8 greckich kwart (chojniks). Ceny więc wykazane w Ap 6,6 są 16 razy wyższe od normalnych na Sycylii, a przeszło dziesięciokrotnie od maksymalnych, ośmiokrotnie od ustawowej ceny określonej przez senat.

${ }_{23}$ Anglosascy komentatomzy wolą tu mówić o ,niedostatku" (very great dearth), nie o ,bezwzględnym głodzie” (absolute famine), który wystąpi jako śmiercionośny już limós po Czwartym Jeźdźcu w Ap 6, 8. Subtelne rozróżnienie, ale dla naszej kontnowersji nieistoitne: na ucisk spoleczny nic nie wskazuje w dalszym ciągu. 
wyjaśnia i nimi rządzi. Rządzi więc i klęskami, które ukazują się pod symbolami jeźdźców; Drugiego, Trzeciego i Czwartego. Czterokkroinne wołanie „Przyjdź!”, co następuje po otwarciu pierwszych czterech pieczęci jest wołaniem eschatologicznym - o paruzję Chrystusa. A zatem poprzez wielkie wydarzenia, poprzez klęski nawet, przycholdzi Chrystus. Tak jest i z Trzecim Jeźdźcem.

Tylko przy opisie otwarcia trzeciej pieczęci zachodzi reakcja na pojawienie się Trzeciego Jeźdźca specyficznie olkreślona: ,usłyszałem j a k b y głos w pośrodku czterech Zwierząt..." Znamienne jest owo ,jakby" (hōs), które nie występuje gdzie indziej przed wyrazem ,głos" ${ }^{24}$. Ta partykuła, odpowiednik semickiego $k^{e}$ jest $\mathrm{w}$ gatunku apokaliptycznym świadomie stosowanym przez autora znakiem wywoławczym określeń tylko przybliżonych ${ }^{25}$. Małe to słówko niejako usprawiedliwivia autora, który tym samym stwwierdza, że brak mu jest w języku ludzkim adekwattnego słowa dla oddania wizji. Owa więc reakcja na Trzeciego Jeźdźca — to jakaś szczególna odpowiedź, nie całkowicie identyczna z głosem. Od kogo pochodzi, można tylko pośrednio się domyślać na podsitarwie okolicznilka „pośrodku Czterech Zwierząt”, czyli — biorąc pood uwagę wizję tronu (Ap 4, 1-5, 8) — od "Zasiadającego na tronie" (=Boga), „Baranka" (=Chrystusa) lub czterech cherubów, opiekunów świata materialnego. Przypuszczenie, że wypowiedź należy do Chrystusa (W. Bousiset), wydaje się najlepiej uzasadnioną, gdyż Bóg $\mathrm{w}$ itej wizji mic nie mówi, jedno ze Zwierząt już zawołało w stronę Chrystusa „Przyjdź”, Jemu więc jako Władcy losów świata przystoi określić rolę zwiastuna, jakim jest Trzeci Ježdziec.

Określenie ,zadania Trzeciego Jeźdźca jest dwuczłonowe. Zapowiedź, typowo biblijna, w pierwszym członie ustala rozmiar klęski głodu niezależnie od tego, czy oba gatunki zbóż mają symboliczne znaczenie sakralne tutaj, czy nie. Raczej podkreśla się powszechıność klęski - włącznie do chleba jęczmiennego, chleba ubogich, o wiele tańszego niż pszenny. Drugi człon - to ograniczenie zadania. Tu dopiero powstaje zagadnienie, jak rozumieć to ograniczenie. Uźycie słowa ,krrzywwdzić" nie wymaga bynajmniej w tym miejscu i w tej książce nieco sztucznego wyjaśnienia, jakie proponuje Brandstaetter: poprzez krzyiwdę biednego człowieka krzywwda po ludzku czujących roślin. Czasownik bowiem adikein ma jeszcze szersze zastosowanie w Apokkalipsie, a znaczy prawie tho samo, co „,szkodzić”. Nie tylko parokrotnie czymność ta oddnosi się do ludzi (np. 2, $11 ; 9,10.19 ; 11,5)$ lub jest synonimem w ogóle złego postępoiwania (22,

${ }^{24} \mathrm{~A}$ w sumie wyraz fōne $\bar{e}$ występuje w Ap aż 52 razy. Poza naszym, hōs występuje w sąsiedztwie ,głosu" tylko w 1, 15, ale tam odnosi się do całości: „jak głos wielu wód”, a w 19, 6 do „potężnych gnomów”.

${ }^{25}$ Por. np. wizję wstępną Ez 1, 4-28, gdzie szczególnie często zachodzi. 
11), ale jej przedmiotem są poza naszą ,oliwą i winem” także: „ziemia” $(7,2 n$.$) i „trawa na ziemi” (9,4)$.

Bardzo trafne jest łączne tralktowwanie zbóż, wina i oliwy jako biblijnych znaków Bożego miłosierdzia. Ale to iunctim tutaj stwarza tylko dodatkơwą trudność: dlaczego ludziom ma 'brakłować dositatecznej ilości dwóch koniecznych zbóż, a zbiory oliwy i wina mają pozostać nietiknięte. Tej znamiennej $\mathrm{w}$ tekście różnicy nie tłumaczy globalne ujęcie przez Brandstaetitera - ostrzeżenie pod addresem krzywwdziciela, gdy tymczasem wykonawca ,gniewu Baranka” czy innego tajemniczego Jego zrządzenia otrzymuje niejednakowe uprawnienia w zakresie klęski. Prawdzilwy problem egzegetyczny stanowi tu tylko właściwy sens owrego ograniczenia klęckki, tego wyjątku uczynionego dlla olliwy ì wina.

Rozwiązania tak sprecyzowanego problemu szły dotąd $\mathrm{w}$ dwóch -z grubsza ujmując - kienunkach. Piemwszy $\mathrm{z}$ nich, reprezentowany już w starożytności, szukał, nie bez racji, symbolicznego znaczenia oljwy i wina, widząc w mich materię salkramentółw Kościoła. Drugi - po dziś dzień woli szukać rozwiązania według klucza hermeneutycznego ówczesnej historii (zeitgeschichtlich) ${ }^{26}$, podając niejedną rację wspomnianego wyljątku dla oliwy i wwina. Przy czym ówczesna historia - to dla jednych autorów rzymskka gospoidarka cezaráw, dla innych - aluzje do spraw palestyńskich, na czele $\mathrm{z}$ wojną żydowską. Gatunek literacki Apokalipsy uprawnia obydwa te kierunki, a także ich połączennie. Stąd mamy dziś wiellkie bogactwo proponowanych rozwiązań, a żadne $z$ nich nie może sobie rościć pretensji do wyłączności, ani też żadnemu $\mathrm{z}$ nich nie można odmóiwić pewnego prawdopodobieństwa ${ }^{27}$. Co najwyżej różnią się te rozwiązania jego stopniem. Po zastosolwaniu trzeźwych zasad hermeneutycznych, wysnutych na podstawie danych niezalwodnych o Apoika-

${ }^{26}$ Ow klucz dawno- już stosowany w nowożytnej egzegezie otrzymał syntetyczne opracowanie: S. Giet, L'Apocalypse et l'histoire, Paris 1957. Autor ten dla Trzeciego Jeźdźca przyjmuje rozwiązanie tradycjonalne, a w argumentacji stosuje tak klisze prorockie, jak dane historii ówczesnej (s. $149 \mathrm{nn} ., 169,190 \mathrm{n}$.).

27 Dlatego w artykule Brandstaettera trudno zgodzić się na polemikę, jaką prowadzi on $\mathrm{z}$ poglądem o. Josepha Bonsirvena SJ, zasłużonego badacza materiałów rabinistycznych. Cytat z mego komentarza jest zniekształcony: słowa ,mniej konieczne do życia" (Bonsirven) przytoczone są w nast. zdaniu: ,Te dwa produkty mniej (!?) są potrzebine (?!) do życia (!?)". Trzykrotnie wyrażone pytajnikami i wykrzyknikami zdziwienie oraz sąd autora artykułu: ,zbyt pochopnie twierdzi J. Bonsirven” nie mają dostatecznego uzasadnienia, gdyż znaczna różnica zachodzi między „,koniecznym" a ,potrzebnym do życia". W wiele lat po juź nie żyjącym J. Bonsinvenie zaostrza ten właśnie jego pogląd współıczesny autor A. Läpple: „Der Befehl, die Herbsternte (Öl und Wein) zu schomen, macht deutlich, dass Genussmittel reichlich vorhanden waren, so dass neben dem Hunger der vielen Schwelgerei und Luxus weniger sehen. Die Waage in der Hand des dritten Reiters ist daher eine lächerliche Farce, denn was Sinnbild der Gerechtigkeit sein sollte, ist in Wahrheit Symbol der Ungerechtigkeit, wird doch für reich und für arm mit sehr verschieden Gewichten gemessen" (Die Apokalypse nach Johannes, München, 1966, 101). Nie solidaryzując się w szczegółach $\mathrm{z}$ poglądem A. Läpplego, podkreślam u niego, podobnie jak u J. Bonsirvena, znawcy spraw palestyńskich, horyzont zmacznie szerszy niż Palestyna. 
lipsie, można próbơwać dawać pienwszeństwo jednymm rozwiązaniom przed innymi.

Naczelną zasadą jest szukanie $\mathrm{w}$ tej księdze sensu eschatologiczmego, niezależnego od uwarunkowań czasowych. Już same warunki, w jakich porwstaje Appokalipsa Janowa, w tę stronę kierują. Księga ta bez wątpienia jest tworem geniuszu Izraela, inspirowana jalk mało która w Nowym Tesitamencie, wzorami staroteistamentowymi. Z drugiej jednalk strony powstaje nie $\mathrm{w}$ Palestymie, lecz w Azji Mniejszej, jalko księga poccieszenia dla chnześcijan, uciśnionych w imperium. rzymskim. Autor patrzy z Patmos nie tyle na wschód (zrobi to w rozdziale 11), ile raczej na zachód, na Rzym. Paleta barw ize Starego Testamentu i z apokaliptyki judaizmu jest w pełni do dyspozycji św. Jana. Tym niemniej koloryt aktualności nadają jej zdarzennia $\mathrm{z}$ widowni całego imperium. Stąd nie przecząc możliwości aluzji plalestyńskich do ,oliwy i wina”, ani reminiscencji z apokaliptyki rabinów ${ }^{29}$, wypada pewne pierwszeństwo dać nawiązaniu do dziwnej sytuacji za Domicjana. W relacji Sweitoniusza ${ }^{30}$ nadmiar produkcji wina wystąpił obolk niedostatku produkcji zbóż.

Wielopłaiszczyznowość symbolów Apokkalipsy skłania do tego, by dopuścić pewwien pluralizm aluzji. Nadto oborwiązująca $w$ tej księdze zasada „rekapitulacji” każe widzzieć $\mathrm{w}$ symbolach wielokmotną ich realizację. A zatem czterej Jeźdźcy Apokkalipsy cwałują wciąż poprzez całe dzieje ludzkie, a kilęski symbolizowane przez Drugiego, Trzeciego i Czwartego będą się poiwtarzać wielolkrotnie jakko zwiastuny dnia sądu Chrysitusa, który tymczasem już rządzi tymi wszysstkimi wypadkami. Ta właśnie prawda jest najważniejszym orędziem, jaikie podaje Apolkalipsia także i przy otwarciu trzeciej pieczęci. Ograniczona w rozmiarach klęska głodu, stały element apolkaliptyczny, podlega też władztwu Chrystusa-Baranka, który dodattkowo jeszcze ogranicza jej działanie. Dla bezpośrednich czytelników Janowej Apoikailipsy niejeden szczegół miał szczególny posmak aktualności. Klęska głodu w czasach Klaudiusza dotknęła Rzym w roku 42, w Judei niedostatek żywności zaznaczył się w roku 45/46, w Grecji — w 49, w Rzymie zaś w $51^{31}$, za rządów Nerona - w r. $62^{32}$. Wśród wielu

${ }^{28}$,Skrzywdzone” zostały przez świętokradztwo zapasy wina i oliwy, zgromadzone w świątyni do celów liturgicznych - przypomina za Józefem Flawiuszem (Wojna żydowska 5, 565) J. D. M. Derrett, Law in the New Testament, London 1970 , $220 \mathrm{nn}$.

${ }_{29}$ I tak niedostatek chleba przy obfitych zbiorach wina zapowiada na czasy, które poprzedzą i wprowadzą przyjście Mesjasza, w Misznie traktat Sota $49^{\mathrm{b}}$, przy czym szczegół, że mimo to wino będzie drogie, naprowadza znawców na przypuszczenie, że jest to cytat z jakiejś apokalipsy żydowskiej. Por. R. H. Charles, A Critical and Exegetical Commentary on the Revelation of St John (ICC), vol. 1, Edinburgh $1950,168$.

30 Żywoty cezarów, Domicjan 7.

31 Por. J. Massyngberde Ford, Revelation (The Anchor Bible 38), Garden CityNew York 1975, 107.

32 Por. Tacyt, Roczniki XV 5. 
więc możliwych roøwiązań zagadniẹnia, jaki fakt konkmetny posłużył św. Janowi ıa punkit wyjścia opisu naistępsitw po otwarciu trzieciej pieczęci, trudno jest zdecydować się na jakiś jeden. Był to zapewne jeden $\mathrm{z}$ ówczasnych kryzysów o rozmiarach ogramiczonych. Korzysistając $\mathrm{z}$ palety proroków Starego Tesitamentu ${ }^{33}$ Wizjoner z Pattmos odmalował go jalko jeden $z$ proodromów paruzji ${ }^{34}$. A skkoro senis obrazów Apoikallipsy nie wyczerpuje się w theściach łatłwo uchwytnych tylko dla wispółczesnego mu polkolenia wiemnych, katwo można zrozumieć także $u$ dzisiejszych komentatorów Appolkallipsy sympatię dla pordanego już wyżej symboliczmego tłumaczenila znanego Ojjcom Kościoła: oliwa i wino, prymitywne środlki lecznicze, znane $\mathrm{z}$ przypowieści o miłosiernym Samaryitaninie ( mają takkże sens nadprzyrodzony ${ }^{35}$. Takk więc Chrystus-Baranek rządzący wypadkkami iwprawdizie zsyła klasyczną w dziejach biblijnych klęskę głodu jalko karę za grzechy, ale w swym miłosiendziu trosszczy się o lek dlla dusz.

Reasumując więc argumenty za interpretacją tradycyjną i zarazem powszechnie dziś podtrzymywaną Trzeciego Jeźdźca jako symbolu klęski głodu - wbrew propozycji nowej, która w zygós - „,jarzmie” i w kontekście widzi uzasadnienie dla symibolu ucisku społecznego, pojętego na sposób zrozumiały w Palestynie ówczesnej - można stwierdzić:

1. Grecki termin zygós może dosksonale być przelkładem helbrajskikiego rzeczorwnika mo'znajîm ze Starego Testamentu, któna tam na wielu miejscach oznacza wagę kupiecką.

2. Znaczenie „wagi” w przelkładzie tenminu zygós odporwiada doibrze czynności skąpego odważania racji żywnościowych - również zgodnie $\mathrm{z}$ wzorami ze Starego Testamentu.

3. Tak rozumiana waga jest dobrze dobranym symbolem klęski głodu, zwłaszcza że w kontekście występują wygórowane ceny artykułów żywnościowyich pierwszej potrzeby.

4. Cały obraz ukazania się Trzeciego Jeźdźca ma zwarty sens, jeżeli się przyjmie, że jest on symbolem klęski głodu.

5. Niezupełnie jasny na pierwszy rzut oka sens dodatkowego zaka-

${ }^{33}$ Por. np. Oz 2, 24; Jl 2, 19; Mi 6, 15: ta ostatnia groźba ma odpowiednik w Pwt 28, $38 \mathrm{nn}$.

${ }_{34}$ Por. H. Schlier, ThWNT II, 468; H. Seesemann, ThWNT V, 166.

35 "Ol und Wein.finden sich auch sonst zusammengestellt; sie sind nicht nur im irdischen Sinne von heilender Wirkung, sondern auch in einem ,über-natürlichen Sinne zum Heile führend. Deshalb wird selbst dem apokalyptsichen Reiter auf dem schwarzen Ross, von Gott als Heimsuchung auf die Erde gesandt, zugerufen: Dem Öl aber und dem Wein füg keinen Schaden zu! (Off 6, 6)". M. Lurker, Wörterbuch biblischer Bilder und Symbole, München 1973, 348. 
zu ikrzywidzenia oliwy i wina dostatecznie się tłumaczy sytuacją gospodarczą imperium $w$ czasie powstawania Janowej Apokalipsy, co zarazem nie przeczy wyższej płaszczyźnie tegoż symibolu.

6. Proponowame ,jarzmo" - warto dodać na końcu — nie byłoby wcale bardziej zrozumiałe dla ówczesnych czytelników obeznanych ze Starym Testamentem, gdyż w nim to słowo miewa również znaczenie wyraźnie dodatnie ${ }^{36}$, nie mówiąc już o tym, że i w ustarch samego Jezusa: „Weźcie moje jarzmo na siebie... Jarzmo moje jest słodkie”. (Mt 11, 29n.).

Tak więc zestawiając tradycyjną i uznaną interpretację Trzeciego Jeźdźca Apolkalipsy, jako symibolu klęski głodu, z propozyıcją Romana. Brandstaettera, godzi się i tym razem powtórzyć ewangelicźne adagium: Vetus melius est.

\title{
TERTIUS APOCALYPSEOS EQUES QUIDNAM SIGNIFICET (Ap 6, 5s.)
}

\author{
Argumentum
}

Novam contra unanimem fere exegetarum huius temporis consensum Tertii Apocalypseos Equitis significationem proposuit Romanus Brandstaetter in speciali articulo (,Tygodnik Powszechny" 23 X 1977), eamque deinde in sua scriptorum S. Iohannis Evangelistae translatione (Warszawa 1978) repetiit. Secundum hune auctorem terminus zygós vertendus est, significatione adhibita primitiva, tamquam „,iugum”, non vero „statera”. „Iugum" vero iniurliae socialis afflictionisque pauperum est imago. Cuius novae interpretationi heic obiicio defensionem eius, quae nunc communiter admittitur, nempe "stateram" tenere Tertium Equitem, qui famis cladem repraesentat.

Erroris causam R. B. apud exegetas suspicatur esse malam lectionem textuum VT, scil. $\mathrm{Lv}$ 26, 26 et $\mathrm{Ez}$ 4, 16. Uterque enim non de instrumento staterae, sed de pondere loquitur. Opinionem vero suam confirmatam videt imagine miseriae operariorum 6 depicta. Verba autem „oleum et vinum ne laeseris" utpote admonitio quaedam contra eos, qui populum pauperem affligunt, diriguntur. Oleum et vinum participationem Iudaeorum in sacris sollemniis prae se ferunt.

Contra ea, quae R. B. asserit, iustum arbitror iter semanticum, quod a pondere per stateram ad famis symbolum ducit. Iustum est vero utpote bene in Vetere Testamento fundatum. Namque vox Graeca zygós in versione Septuagintavirali et instrumentum ( $m \ominus^{\prime} z n a j \hat{\imath} m$ ) et actionem ponderandi complectitur. Quae vero actio ponderandi stricte cum clade famis connecti in VT manifestum est. Symbolicae enim actiones, quas Jahwe iubet perficere Ezechielem prophetam, inter alia et ponderationem supponunt (Ez 4, 10). Parcissima annona diurna, quae apud Prophetam futuram famem Hierosolymorum praesagit, prius certo certius est ponderanda in statera. Interea distinctio stricta inter zygón et stathmón, quam R. B. inculcat, reapse caret fundamento, quod vel optime comparatione facta Is $40,12^{\text {de }}$ in textu hebraeo et versione LXX apparet, ubi uterque nedum distinctus, immo vero mutuo commutandus est. Statera autem in manu Prophetae ante aliam actionem symbolicam usur-

36 Por. np. Lm 3, 27; Syx 21, 25; 51, 26. 
panda iubetur $(\mathrm{Ez} 5,1)$. Praeterea non minimi est momenti vocem zygós in Ap 6, 5 iam ab antiquis versionibus (Vetus Latina, Vulgata, duae syriacae) tamquam „stateram" redditam esse.

Communis et traditionalis interpretatio symboli Tertii Equitis insuper eo confirmatur, quod illae tres clades: bellum, fames et pestilentia, quae permultis mortem affert, persaepe apud Prophetas obveniunt, uti patet ex tabula n-ro 17 exhibitita. Insuper aliae clades invicem interdum commutantur, fames numquam deest. Mirum sane fuisset Apocalypseos auctorem tam frequenter Prophetarum imagines typicas adhibentem famem inter clades omisisse. Non secus in apocalypsi synoptica, quae dicitur, inter nuntios secundi Christi adventus semper adest fames (Mc 13, 8; Lc' 21, 10s; Mt 24, 7s). In ipsa autem Apocalypsi Iohannea imago haec etiam in 18, 8 re-petitur.

Suam interpretationem novam R. B. corroborare satagit iis, quae in 6,6 a voce mysteriosa dicuntur. Denarium enim ad instar Mt 20, 2 diurnum operarii salarium cerealium de penuria clare testantur similiter ac in $2 \mathrm{Rg} 6,25$. Vetatur vero laesio denarius non tam est diurnum salarium, quod reapse illis temporibus vario modo aestimabatur (a dimidio usque ad duos), sed mensura pecuniae. Pretia vero duorum cerealium de penuria clare testantur similiter ac in $2 \mathrm{Rg} \mathrm{6,} \mathrm{25.} \mathrm{Vetatur} \mathrm{vero} \mathrm{laesio}$ olei et vini - secundum R. B. - utpote quae pauperes a sacro liturgico arceret.

Sobriae vero interpretationis principia sensum Vocis in 6,6 , fortasse ipsius Agni-Christi, recte intellegi suadent aut prorsus symbolico modo Ecclesiae Patribus iam noto de praeservatione sacramentorum Ecclesiae aut ratione habita rerum gestarum illius temporis, et quidem potius imperii Romani quam solius Palaestinae, de frequente tum clade famis sub Claudio et Nerone, deque decretis agrariis Domitiani. Illis factis colorem apocalypticum more Prophetarum applicat s. Iohannes, qui ea nuntios parousiae Christi vult esse non semel iteranda secundum principium, ,recapitulationis". Nam res gestes illius temporis, quo mysteriorum revelationem conscribebat Videns in Patmo, minime totum imaginum eius sensum exhauriunt, cum totum mundum et omnia saecula imagines Apocalypseos exhibuerint.

Insuper „iugum" a. R. B. propositum haud facile intellectu esset primis Apocalypseos lectoribus, utpote qui ex Vetere Testamento etiam honorificam vocis significationem norint (vg. Lm 3, 27; Sir 21, 25; 51, 26), a Domino (Mt 11, 29s) confirmatam.

Interpretatio igitur a saeculis nobis tradita eaque hodie communis, nempe Tertium Apocalypseos Equitem famis cladem significare tamquam parousiae prodromum, multo melius fundata apparet quam recens propositum symbolum iniuriae socialis, iugo expressum. 